\title{
ROMANTIC ELEMENTS IN LAXMIPRASAD DEVKOTA'S MUNA-MADAN
}

\author{
Dharma Bahadur Thapa \\ Associate Professor, Department of English, Birendra Multiple Campus, Bharatpur, TU. \\ Corresponding author:dhrm.thp@gmail.com
}

\begin{abstract}
This article is an attempt to study Laxmiprasad Deckota's poetic work Muna-Madan to see how much it concords the romantic philosophical parameters. It analyses the textual properties of the work on the basis of romantic principles and philosophy propounded by William Wordsworth in his famous essay "Preface to Lyrical Ballads." It also invokes C. W. F. Von Schlegel's poetic theory and the philosophically grounded definitions of romanticism given by authors like Bertrand Russell, Justin and Gaarder. Finally the paper comes to the conclusion that Devkota's Muna-Madan contains all the major characteristics like strong subjectivism, foregrounding of folk culture, privileging the common over the sophisticated and spiritualization of nature that a romantic poetry should possess.
\end{abstract}

Keywords: romanticism - rustic - nature love - self-expression.

\section{INTRODUCTION}

Laxmiprasad Devkota, the composer of the path breaking ballad Muna-Madan, is famously known as Mahakavi Devkota (epic or great poet) in Nepali literature. Despite being a rare genius who could write many epics and who excelled in every genre of literature, it is Muna-Madan which is said to have credited the poet the identity of greatness. These have become a part of very commonplace knowledge among the literary circle in Nepal and anybody who has preliminary sort of knowledge of Nepali literature. This article attempts to explore and seek how the poem underlies the European Romantic tradition. Keeping in view the limitations of space of the paper, it does not dwell upon the matters like the poem's immense popularity, Devkota's literary genius, his total literary output, his contribution and place greatness and the circumstances of his life and death. The paper introduces the theoretical premises and characteristics of 
romanticism and, side by side, shows how Muna-Madan abounds in these features.

Although there are a few translated versions of Muna-Madan in English, it uses the original Nepali version of the poem for the analysis. Conforming to the academic practice I have quoted from the primary text first in the Roman script of the Nepali equivalent and then translated it into English keeping inside square brackets. Preferably, I have used Christian year in the paper but wherever I have to use both, I have put the Christian era inside square brackets. In the translation I have attempted to preserve the sense than the literal meaning of the quoted lines. The paper categorically deals with the basic tenets of romanticism like interest in folk culture, innovation in form and content, projection of the poetic persona in the poem and idealization of natural phenomenon

\section{LITERATURE REVIEW}

Muna-Madan is one of the few poetic works in Nepali literature which has elicited such a huge amount of critical discussions, comments and acclaims. It has been analysed and interpreted by innumerable scholars using various theories and perspectives and search and research has not waned. Bandhu (2010), for example, contends that it contains social ideal and the main cause of its love story of the married couple is the main cause of its immense popularity (p. 40). Dube (1970) interprets its theme as the triumph of the spiritual over the material (p.150). Thing (1989) examines the mini epic from Marxist point of view and concludes that it is a great achievement for the Nepalese literature for its revolutionary epoch making humanitarian social revolutionary national consciousness (p.169). Pradhan (1988) attempts to investigate the poem from the psychological theory developed by Freud and interprets the dreams of the characters Madan and Muna had in terms of sexual desires. He asserts that the image of the queen of Bhot [Tibet] bathing in milk and the dream Muna had the expression of their strong unfulfilled erotic impulses (p.276). Aryal (2007) has analysed it from the point of view of the characterization of women like Muna, Aama [mother], Didi [elder sister], and Naini and concludes that "naari chitranka dridhtibaata yo kaavya safal ra utkrishta dekhincha [this poem is successful and excellent from the point of view of women charaterization]" (p.270). Awasthi (1998) applies Kuntak's "Vakroktivaad [Defamilirization]" theory to examine its beauty derived from the juxtaposition of multiplicity of sounds (p. 300). Gautam (1991) designates it as a great poetic creation on 
five counts: impermanence of wealth, naturalness, simplicity, contentment of the heart and higher pleasure (p.81). He also advances that it contains the philosophies of the eastern sages, Gandhi, Rousseau and romanticism (p.85). Pradhan (1991) examines the poem from aesthetic point of view and asserts that it is greatest tragic lore in the Nepalese literature and ascribes its popularity to its beautiful and natural juxtaposition of metaphors (p.367).

Notwithstanding profusion of interpretations with multiplicity of the approaches, there have been very little and sporadic references to the poem's association with the European romantic philosophical traditions and trends of view. Therefore, an in-depth analysis of the poem completely focused on romantic philosophical parameters is still a task worth undertaking. The following section of the paper undertakes to fulfil this need.

\section{What is romanticism?}

Gaarder (1991) sees Romanticism as Europe's last common approach to life that began toward the end of the eighteenth and lasted till the middle of the nineteenth century. He adds that it started in Germany as a reaction to the Enlightenment's unequivocal emphasis on reason (pp.34546). In other words Enlightenment or the age of reason overemphasized the values of decorum and the established classical rules of correctness in a literary composition. The writer used to follow the fixed generic norms or conventions, in both content and form. Abrams (1993) advances that romantics favoured innovation against this "traditionalism in the materials, forms, and style of literature" (p.127). In other words Romantic Movement, going against the prevailing literary fashion, sought for and foregrounded the values which were innovative and ignored or sidelined during the Enlightenment period.

In a nutshell, opposed to restraint and strict adherence to established conventions, romantics advocated and practised a free play of imagination, innovation and self expression in their poetic compositions. Such tendencies are strongly found in the British romantic poets like William Wordsworth, S T Coleridge, P B Shelley and others. In the succeeding section of the paper, I deal with the textual and contextual features of Muna Madan in the spotlight of specific romantic characteristics to show how it meets the romantic criteria.

\section{Muna-Madan and literary context}

Laxmiprasad Devkota wrote Muna-Madan in 1936 (Devkota 2018 , p.i). His contemporaries and predecessors were heavily influenced 
by Sanskritized contents, language and metrical pattern. Lekhnath Poudel and Somnath Sigdel, for example, wrote poems in strict metrical forms. Motiram Bhatta, on the other hand, specialized in amorous versus. In those days, as Devkota (2018) stresses, Sanskrit education was in the norm and it was the language of education of the elite class and literature. Nepali, the vernacular, was the language of the working class and was looked down on among the literary circle (p.ii). He further elaborates that literature was all about gods, kings and beauties (pp.iii, iv, v). This means that poetry written about/for common people, written in the language used by them would not be accepted as literature. To a greater extent, it parallels with the emergence of romanticism in Britain in the age when grand subject matter and elevated style were demanded in poetry. Amidst such adverse context Laxmiprasad Devkota came up with a long narrative poem which has the native origin, which is about the common people and which is written in jhyaure, a form of Nepali folk meter.

The context of the publication of Muna-Madan parallels with the inauguration of English Romantic Movement. Wordsworth and Coleridge jointly published Lyrical Ballads in 1898 with the Preface which heralded the age of romanticism. They needed the apology for their poems because they were marking a shocking departure from the tastes of the poems of preceding period. In the Preface Wordsworth (1992) throws light on the qualities of poems that the reader should anticipate. He advances his principle in these terms:

The principle object, then, proposed in these Poems was to choose incidents and situations from common life, and to relate or describe them, throughout, as far as possible in a selection of language really used by men, and, at the same time, to throw over them a certain colouring of imagination, whereby ordinary things should be presented to the mind in an unusual aspect ... Humble and rustic life was chosen, because in that condition, the essential passion of the heart find a better soil ... because in that condition of life our elementary feelings co-exist in a state of greater simplicity ... (p.164)

Wordsworth's poetic theory emphasizes that the subject matter of poetry should be taken from the life of the common people and its language also should be the language of the common people. In parallel with Wordsworth's principle, Devkota (2015) also begins his poem with Samarpan [Offering] and Sajjanwargaka Prati [To the Humble Fold]. To cite some lines of the latter: 
yo fulijaos! Yo failijaos! Basanta dakana,

jhyaure bhani nagara hela he pyara sajjana!

[Let it blossom forth! Let it spread! To call spring,

Oh my dear humble readers don't look down on it for being folk song!]

Jhyaure is the type of folk song that is sung collectively in working places. Such songs are not written down but spontaneously and instantly produced by the singers according to the demand of the situation. Such songs, during the time of the poet composed it, did not meet the criteria of literature. However, Devkota is confident that his poem is going to make a stir among the traditional minded literati. He was also aware that writing a folk poem in the Sanskrit dominated atmosphere is like going against the tide. However, he is also sure that his poetic work is going to prove a landmark in the history of Nepali literature. In the penultimate couplet he further pleads:

Yo mero saarwajanik savda sabaile soonnechhan,

Aadima tara naveen chijko wajana gunnechhan.

[I hope everybody will listen to my public appeal

They will feel the gravity of the thing which is primitive but new.]

This couplet, undoubtedly, is an apology for the poem directly addressed to the public hoping that it will be accepted and valued. He calls his poem primitive and new. It is primitive because it is production of the 'lowly life' of the common people. It is new at the same time because it has not been treated and tasted like literature before. To use today's fashionable parlance Devkota has attempted to deconstruct the classical tradition of poetry by trying to bring into the centre which was once in the margin.

\section{The source of the poem}

The story of Muna-Madan stands on the common native culture in two ways. First of all, as people of dependent country, Nepalese youths have tradition of working in the foreign land as low paid workers or mercenary soldiers so that they can earn a little to fulfil the needs. Chapagain (2020) asserts that "The epic makes a heart-rending depiction of the life of lower middle class people" (para. 18). The aspirations of Madan, the protagonist, represent the aspirations of such youths and Muna represents the young wives who desire their husbands rather stay with them than go to unknown places for financial quest. Muna expresses her preference for hardships and 
scarcities than separation with her husband. She represents thousands of young women whose husbands are in faraway lands for employment. This culture has still retained with considerable modifications in the love faith and devotion between couples. Secondly, the plot of the story is adopted from a Newari folk ballad (Joshi 1991, p.58). Therefore, the story has the native footing. Devkota (2018) in "Introduction" to his English translation of Muna-Madan mentions that the source of the poem is a Newari ballad where the protagonist, Merchant Udas, obeys his mother and prepares to go to Lhasha to trade. Despite his wife's plea not to go and leave her behind, he leaves home. When he is away, someone informs his wife that her husband has died. She cannot bear the shock of this news and falls down dead. (p.xxx)

Of course, Devkota makes a lot of modifications and alterations; the main frame work of the plot is this folk tale. In Devkota's version, the mother is not shown forcing the son to go away to Lhasha and Madan is not a merchant like Udas.

To take interest in folk culture and render it literary quality is one of the main characteristics of romantics. Gaarder discusses the differences between two varieties of romanticism: Universal and National. The former refers to the school which is preoccupied with nature, world soul and the latter to the culture, language and history of the people. He cites the example of Herder as a National Romantic who collected folk songs from different parts of Europe ( p.352). Devkota has exactly done like what Herder and other European romantics have indicated.

\section{Bhote: An epitome of rusticity and humbleness}

A minor character from the point of view of the role assigned, Bhote or Lama in Muna-Madan occupies the central position from the romantic philosophical point of view and the moral values he stands for. Romantic philosophers and writers privileged the rustic life to the sophisticated civilized living. The underlying notion is that being close to nature, rustic living is farther away from the corrupting effects of civilization. In other words rusticity prefigures the state of Edenic untainted innocence and simplicity in the romantic imagination. Romantics are said to have been influenced by Rousseau's slogan 'back to nature' (Gaarder p.349). Russell (2002) explains that "The poor were supposed to possess more virtue than the rich; the sage was thought of as a man who retires from the corruption... to enjoy the peaceful pleasures of an unambitious rural existence" (p.651). 
Wordsworth also stresses that "humble and rustic life" is free from "the influence of social vanity" ( p.164). Lohani (2020) opines that Bhote is "altruistic ... a rustic character- simple, natural and noble" foil to the villain corrupted by “civilization" (para. 9). In Devkota's (1997) opinion he represents the man of primitive state in which violence has not found its place yet (p. 253). Bhote/Lama is such a virtuous, humble and rustic character who is free of social vanity and corruption.

Before analysing the role of Bhote or Lama, I feel it necessary to define these terms. The word 'Bhote' literally means someone from Bhot or Tibet. In Nepali usage it indicates the ethnic group known as the Tamang who must have migrated from Tibet hundreds of years back. They are the greatly marginalised people who inhabit in the remote high hills around the Kathmandu Valley. Lama, on the other hand, is the priestly class of this group. To this character Devkota has given the group identity instead of designating the character with an individualized name and he has used both terms without any distinctions.

Madan starts returning home as he thinks he has earned sufficient enough to get his aspirations fulfilled. He catches cholera in the forest on the way back home. His friends desert him, saying that it is not beneficial to waste time for a dying person. Mean time, there arrives Bhote, treats and gives him shelter. Madan realizes:

Chhetriko chhoro yo paau chhunchha ghinale hoondaina;

Manisa thulo dilale hoonchha jaatale hoondaina. (p.20)

[Despite being a son of a noble I touch these feet without ill feeling;

A man is great not by birth but by great heart.]

In the Hindu culture to touch someone's feet is to honour or express gratitude to the person. It is a surrendering or a form of supplication. Only the feet of gurus, parents and other superiors are touched. Here Madan renounces the vanity and pride based on birth, social rank and so called superiority of upper caste. At the same time the kind and selfless attitude of Bhote contrasts the selfish and business minded behaviour of Madan's friends who have deserted him in the time of need. Madan survives because of the Bhote's selfless service and devotion.

Dwelling far away from the pollution of civilization amidst the purity of pristine natural surroundings of forests and high hills, Bhote epitomizes the romantic ideal of humanity. Romantics believed in the 
organic unity between man and nature (Gaarder, p.352). This implies that natural environment one lives in has direct bearing on one's character. Bhote and his livelihood are presented as:

Muskaanma chhaina maancheko chhoori, wachhanma chhaina wish,

Haawama chhaina dooshana kehi, manama raaga ris,

Daaridhrya tyahan kya dhani thiyo, thoraima kati dher!

Chhahindo raichha ke sookhalai? Prakriti vaye ner! (p.21)

[No hidden knife in man's smile, no poison in speech,

No pollution in the air, nor jealousy and scorn,

Scarcity was wealth there, and plenty in few!

Once one is close to nature, nothing needed for happiness!]

These paradoxical lines abound in richness of meanings. On one hand the poet draws a sharp contrast between the treachery, duplicity and artificiality of the so called advanced or civilized people and on the other, the honesty, simplicity and openheartedness of the people who live in nature's proximity. Civilization has taught man to be deceptive and it has polluted nature too. Subedi (1997) comments that Bhote represents the great spirit of humanism (p. 181). Contrast is also drawn between wealth and poverty. Civilization is measured in terms of physical prosperity, but there is scarcity of warmth of human heart. On the contrary, the poor, though suffer from scarcity of wealth, are rich because they live amidst nature and hence they have human heart. The same idea is further highlighted in the line, "Shaharmaa bhari jiwana bhanchhan jiwana ta thiyo wan" [People say there is life in the city but life was in the forest.] (p. 21). The contrast between Madan's friends and Bhote, wealth and poverty, and between the city and the forest highlights the superiority of rustic and humble life.

\section{Divinity in nature}

Romantic poets are grossly designated as nature lovers. According to Abrams (1993) the landscape, together with its flora and fauna became a persistent subject of poetry and was described with an accuracy and sensuous nuance (p. 128). Natural description, however, is presented not only for the sake of its superficial visual beauty. More than this, the poets spiritualized nature. Gaarder informs that Schelling was the leading romantic philosopher who wanted to unite mind and matter. All of nature is 
the expression of one Absolute or the world spirit. In other words, nature is the visible expression of God. Schlegel (1990), another powerful influence on romantics, also believed that the higher and spiritual world can be everywhere embodied and shadowed forth in our terrestrial materials ( $\mathrm{p}$. 22). Altogether, romantics treat nature as more than material phenomenon; rather they treat it as a spirit or the manifestation of God.

Devkota's Muna-Madan is rich in vivid and lively description of natural beauty. Upadhaya (1999) commends the poem for its description of the Himalayan natural phenomenon (p. 117). Khanal (2008) also maintains that this poem is richly coloured in romantic nature worship (p. 237). As a romantic poet, he has also treated outer natural phenomena as the expression of the power of God influencing the human spirit. As I have already mentioned, in the humanist spirit of Bhote, his being close to nature has influenced his character. A few more extracts from the poem illustrate how Devkota presents the beauty of nature:

Nakali gyana pothika bhanda, fool paanaa hansilaa

Rangilaa patra prakritdevi ultanthin rasila,

Ishwarako jyoti talkanthyo tyahin shitaka daanaamaa,

Kya bolthyo Ishwar pakherubaata rangeena gaanaamaa! (p. 21)

[The blossoms impart knowledge more delightfully than the artificial volumes of books

The colourful pages of nature goddess unfold the juice of knowledge

The light of God would sparkle in the drops of dew

He would speak in the mellifluous chirping of birds from the hills.]

In the above lines nature is taken as 'nature goddess' and 'birds' songs from the hills are the voices of God and sparkling dew drops represent God's light. In other words, as mentioned earlier, nature is visible aspect of God and God is invisible form of nature.

\section{The intruding ego: Expression of the poet's self}

Abrahams opines that much of romantic poetry invites the reader to identify the protagonists with the poets themselves ( p. 128). This means that poetry is the self expression of the poet rather than of an impersonal character. Gaarder calls it 'ego worship' ( p. 346). Ego worship has resulted 
in the unrestrained free play of the poet's imagination in the act of poetic creation.

Certainly in Muna-Madan Devkota is not the protagonist, nor does Madan represent the poet in the least. In that sense it is not a work of self expression. However, the reader can feel a strong presence of the poet persona in Muna-Madan. In this regard Gautam remarks that Devkota concludes the poem as one of the characters (p. 93). The poet projects his personality into the poem in two ways: first through the direct narrative voice in the prologue and epilogue and secondly, in the delightful vivid description of natural phenomena.

As mentioned earlier, Muna-Madan begins with Samarpan [Devotion] and Sajjanwargka Prati [To the Humble Fold] which are not the integral part of the narrative, yet they are essential part of the overall design of the work. In both of them Laxmiprasad Devkota makes his presence in the first person 'I'. Madan returns home with gold for Muna and the mother. His sister relates him the death of both of them. He is heartbroken and left without his dear ones and a purpose. He wails for the death of his dear wife and mother and desires death for himself. The narrative ends in a very intensely tragic note. But the poem does not end with the completion of the story. The poet concludes the poem with his personal didactic voice which attempts to compensate the tragic end:

Prithivimaa basi swargamaa herne chhan haamraa najara,

Tala nai hari tala nai heri bilaunaa nagara,

Manako batti tanalo bali swarga chha prasada,

Karma mai pooja ishawara bhanchha yo Laxmiprasada.(p.40)

[We fix our gaze on to heaven sitting on the earth,

Do not wail looking down again and again,

With the sacrifice of the body and holding the inner light, heaven is the reward,

I, poet Laxmiprasad, urge to worship God in the form of work.]

These are the concluding lines of the epilogue, although a separate topic is not given unlike in the beginning. It contains five rhyming couplets which bear the poet's optimistic philosophy. Bandhu maintains that the poet has made direct presence to conclude with his didacticism ( p. 171). The 
scope and purpose of the article is not an explanation the poet's philosophy in the poem but only to see how strongly Devkota projects himself into it.

As indicated earlier, Muna-Madan is more than retelling of a folk tale which was already familiar among the Newar community. It is a reworking on the available raw materials which undergo a big change in the poet's hand. The poet embellishes and enriches it with his romantic outlook, namely, the vivid description of flora and fauna as the corporeal manifestation of God. On his way to Lhasa, Madan goes through the beautiful Himalayan landscape. Madan's visual perceptions of nature's sublime are in reality, the poet's own perceptions and love of nature. To this extent Madan represents the poet. Therefore, as a romantic poem, MunaMadan contains a strong presence of the poet persona.

\section{CONCLUSIONS}

The discussion leads to the conclusion that Laxmiprasad Devkota's Muna-Madan meets all criteria of romantic poetic work. It was published in the age which was heavily guided by strict Sanskritized classical tradition which shunned the folk literature. The narrative the poem tells is based on the folk tradition. It is written in simple language which is used and can be easily grasped by the general mass. It privileges the common man to the so called civilized one and guided by humanitarian values. It abounds in the description of the beauty of nature as the physical manifestation of the immaterial spirit commonly designated as God. Though Madan, the protagonist of the poem, does not completely represent the poetic persona, the poet makes a strong presence in the poem. All these features make Muna-Madan a great romantic poetic work rooted in native flavour and tradition in the Nepalese literature.

\section{REFERENCES}

Abrams, M. H. (1993). A glossary of literary terms. 6th ed. Banglore: Prism Books Pvt. Ltd.

Aryal, P. (2007). Muna Madanma naari chitran. In: Nepal, S.P. (ed.) Munamadan Samalochana. Kathmandu: Mahakavi Devkota Shatavdi Maotshav, pp. 270-270.

Awasthi, M. (1998). Vakravinyaaswakrata ra Munamadan ma tyesako Prayog. In: Nepal, S.P. (ed.) Munamadan Samalochana. Kathmandu: Mahakavi Devkota Shatavdi Maotshav, pp. 294-304.

Bandhu, C. (2010). Devkota. Lalitpur: Sajha Prakashan. 
Chapagain, N. (2020 November 15). Memorable Aspects of Poet Laxmi Prasad Devkota. The Gorkha Times. http://thegorkhatimes.com, Accessed: 02.12.2020.

Devkota, L. (2015). Muna-Madan. 27th ed. Lalitpur: Sajha Prakashan.

Devkota, P. (1997). Munamadan ra himali utopiya. In: Nepal, S.P. (ed.) Munamadan samalochana. Kathmandu: Mahakavi Devkota Shatavdi Maotshav, pp. 248-259.

Devkota, P. (2018). Introduction. In: Devkota, L.P. (ed.) Muna-Madan. Trans. Padma Devkota. Lalitpur: Adarsh Books. (i-lxix).

Dube, C. (1970). Muna Madanko adhdhyamik pratik. In: Nepal, S.P. (ed.) Munamadan samalochana Kathmandu: Mahakavi Devkota Shatavdi Maotshav, pp. 150-157.

Gaarder, J. (1991). Sophie's world. Trans. Paulette Moller. New York: Berkley Books.

Gautam, K. (1999). Munamadan: Ek uttam kriti. In: Nepal, S.P. (ed.) Munamadan samalochana. Kathmandu: Mahakavi Devkota Shatavdi Maotshav, pp. 80-100.

Joshi, K.B. (1991). Devkotaka pramukh kavita kritiko kaalkramik vivechana. Kathmandu: Shidhdhartha Banasthali Pragyik Parishad.

Kahnal, N.P. (2008). Munamadanma alangkaar saundarya. In: Nepal, S.P. (ed.) Munamadan samalochana Kathmandu: Mahakavi Devkota Shatavdi Maotshav, pp. 229-237.

Lohani, S. (2020). Love life and death in Muna Madan. DSRC. dsrc.org. np/navigation/65-articles-on-the-poet-devkota-html, Accessed: 01.12.2020.

Pradhan, P. (1988). Fraidiya swapna shidhdhantama Munamadan. In: Nepal, S.P. (ed.) Munamadan samalochana. Kathmandu: Mahakavi Devkota Shatavdi Maotshav. pp. 273-293.

Pradhan, R. (1991). Munamadan: Janapriyetako aadhaar. In: Nepal, S.P. (ed.) Munamadan samalochana. Kathmandu: Mahakavi Devkota Shatavdi Maotshav. pp. 360-368.

Russell, B. (2002). History of western philosophy. London: Routledge.

Schlegel, C.W.F. v. (1990). Lectures on the history of literature, lecture 12. In: Seldon, R. (ed.) The theory of criticism. London and New York: Longman. pp. 21-23. 
Subedi, D. (1987). Munamadanko lokpriyetako karan In: Nepal, S.P. (ed.) Muna-Madan samalochana. Kathmandu: Mahakavi Devkota Shatavdi Maotshav. pp. 178-185.

Thing, J. (1989). Pratakchya manavvaadi Devkota ra Manamadan. In: Nepal, S.P. (ed.) Muna-Madan samalochana. Kathmandu: Mahakavi Devkota Shatavdi Maotshav. pp. 173-177.

Upadhaya, K.P. (1999). Munamadanko nichod. In: Nepal, S.P. (ed.) MunaMadan samalochana. Kathmandu: Mahakavi Devkota Shatavdi Maotshav. pp. 106-122.

Wordsworth, W. (1992). Preface to lyrical ballads. In: Enright, D. J. \& Chickera E. D. (eds.) English Critical Texts. Delhi: OUP, pp. 162189. 